\title{
ON THE DYNAMICS OF BUSINESS CYCLE ANALYSIS: EDITORS' INTRODUCTION
}

\author{
DICK VAN DIJK, HERMAN K. VAN DIJK AND PHILIP HANS FRANSES \\ Econometric Institute, Erasmus University Rotterdam, The Netherlands
}

The business cycle is a concept of key interest for all economic actors alike. One can think of consumption and savings decisions of individual consumers, production decisions of private sector firms, and monetary and fiscal policy decisions of central bankers and the government. All can benefit from accurate forecasts of the future development of economic variables, which to a large extent depend on the business cycle. The characterization of the business cycle, and the analysis of its properties, has been the subject of innumerable studies. It is widely recognized that business cycle research started with, or at least was boosted by, the seminal work of Burns and Mitchell (1946) and the preceding work on statistical testing of business cycles by Jan Tinbergen (1939).

\section{JAN TINBERGEN (1903-1994)}

In April 2003 a conference entitled:

\section{On the Wealth of Nations, extending the Tinbergen Heritage}

was held at Erasmus University Rotterdam honouring the centennial birthday of Jan Tinbergen. One of the purposes of this meeting was to exchange and discuss recent developments in business cycle analysis and related research. Leading scholars in the field presented their latest work. A carefully selected and refereed set of papers from the conference is collected in this special issue.

A few key elements in the work and life of Jan Tinbergen relate to this special issue. Tinbergen started his academic career studying physics with Ehrenfest at the University of Leiden. However, as a young student he was shocked by the poor living conditions of the local population. After obtaining his doctorate degree in 1929 , he decided to become an economist in order to attempt to make a contribution to the solution of the depressed economic conditions of his time. His many academic papers and books were always inspired by social economic problems. During his long life Tinbergen himself was a source of inspiration to many others. Together with Henri Theil he was the founding father of econometrics in the Netherlands and in particular in Rotterdam where, partly on his instigation, the Econometric Institute was established in 1956, with Theil as the first director. In the latter part of his career Tinbergen focused more on issues related to income distribution, economic planning and development economics, acting as an advisor to the governments of several countries.

A major recognition of Jan Tinbergen's work was the fact that, jointly with Ragnar Frisch, he was awarded the first Nobel Prize in Economics in 1969 'for having developed and applied dynamic models for the analysis of economic processes'. Excerpts from the speech by Professor

Copyright $@ 2005$ John Wiley \& Sons, Ltd. 
Erik Lundberg on the occasion of the presentation of the Nobel Prize give a good characterization of Tinbergen's work as it relates to the analysis of business cycles (Lundberg, 1969):

Since the late twenties, Professor Frisch and Professor Tinbergen have been working along essentially the same lines. Their aim has been to lend economic theory mathematical stringency, and to render it in a form that permits empirical quantification and a statistical testing of hypotheses. One essential object has been to get away from the vague, more 'literary' type of economics.

Professor Tinbergen was concerned primarily to confront dynamic economic theory with statistical application. His great pioneer work in this field is an econometric study of cyclical fluctuations in the United States. An important aim in this impressive investigation was to test the explanatory value of the existing flora of business cycle theories by trying to specify, quantitatively, the importance of different factors.

Professor Tinbergen's pioneer work in econometrics has been of major importance for subsequent methodological development.

Professor Frisch, Professor Tinbergen, You have both been pioneers in the development of economics into a mathematically-specified and quantitatively-determined science. Your contributions in creating a rational foundation for economic policy and planning with the help of well-developed theory and statistical analysis have involved a major scientific breakthrough.

\section{THIS SPECIAL ISSUE}

Despite the abundance of theoretical and empirical research on business cycles, there are still many questions for which no firm answers have yet been given. A non-exhaustive list of open issues, with an indication as to how the different papers in this volume contribute, is as follows:

\subsection{Definition and Measurement of Cycles}

Meaningful research and discussions of cycles requires a clear definition of the concept. As discussed in the paper by Harding and Pagan, several definitions and interpretations of 'cycles' are in common use, which may lead to unnecessary confusion. A well-structured framework for classification of cycles is called for, and Harding and Pagan provide several useful suggestions in this direction.

\subsection{Shocks, Propagation and Transmission of Cycles}

Ample research has been (and still is) devoted to investigate shock propagation mechanisms in different economies and their effects on cyclical behaviour. The three papers by Smets and Wouters, by Peersman and by Wallis and Jacobs address this issue for the USA, Euro area and UK economies using different macroeconometric modelling approaches. A related (more recent) question of interest is whether business cycles are 'contagious', that is, whether business cycles are transmitted across countries, regions and industries and how this actually occurs. Canova, in his analysis of the transmission of US shocks to Latin America, documents that especially US monetary shocks have pronounced effects, where the financial channel plays a crucial role in the transmission. 


\subsection{Common Cycles and Convergence}

Ever since Burns and Mitchell (1946) described the business cycle as consisting 'of expansions occurring at about the same time in many economic activities, followed by similarly general recessions' there has been a great deal of interest in cyclical co-movements of different macroeconomic variables. Gradually this also led people to investigate questions concerning the presence and importance of a common business cycle across sectors, regions or countries. The paper by Smith and Summers is an example of recent approaches to the issue of synchronization of cycles using nonlinear time series models. Carvalho and Harvey address the related question of whether there is convergence of cycles among EMU countries.

\subsection{Nonlinear and Time-Varying Characteristics of Cycles}

The notion that business cycles are asymmetric has long been around. Keynes (1936, p. 314), for example, already noted that 'the substitution of a downward for an upward tendency often takes place suddenly and violently, whereas there is, as a rule, no such sharp turning point when an upward is substituted for a downward tendency'. Consequently, nonlinear time series models have been used extensively to characterize business cycle asymmetries, mainly focusing on the different dynamics during expansions and recessions. In their contribution to this special issue, Kim, Morley and Piger consider a Markov-switching model, which incorporates a 'bounce-back' effect to accommodate the observed rapid recovery from recessions. A more recent empirical observation is the substantial reduction in volatility of cyclical fluctuations in the USA and other developed countries.

\subsection{Cycles in Financial Markets}

Financial variables such as interest rates and stock returns have a strong track record as powerful leading indicators of turning points in the business cycle. More recently, attention has been given to the existence of cycles in financial markets themselves. In this volume, Koopman and Lucas analyse cycles in credit spreads and business failures, also considering the possible interaction with the macroeconomic business cycle.

The papers collected in this issue show that business cycle analysis still is a relevant and fruitful research area. Since Tinbergen's seminal contributions, new insights have been obtained, and we believe that many more will be needed.

\section{ACKNOWLEDGEMENTS}

A major conference can only be organized successfully with the help of many individuals. For financial assistance we are indebted to the Royal Netherlands Academy of Arts and Sciences, The Erasmus University Trust Fund and the Econometric Institute. We are also grateful to members of the Econometric Institute for their helpful assistance, and in particular to Tineke Kurtz, Elli Hoek van Dijke and René Segers.

\section{REFERENCES}

Burns AF, Mitchell WC. 1946. Measuring Business Cycles. National Bureau of Economic Research: New York. 
Keynes JM. 1936. The General Theory of Employment, Interest, and Money. MacMillan: London.

Lundberg E. 1969. Presentation speech for the Bank of Sweden Prize in Economic Sciences in Memory of Alfred Nobel. http://www.nobel.se/economics/laureates/1969/press.html.

Tinbergen J. 1939. Statistical Testing of Business Cycle Theories, Volume II: Business Cycles in the United States of America, 1919-1932. League of Nations: Geneva. 